Gut, 1972, 13, 920-925

\title{
Effects of phenobarbital and rose bengal on the ATPases of plasma membranes of rat and rabbit liver ${ }^{1}$
}

\author{
Y. LAPERCHE, A. LAUNAY, AND P. OUDEA with the technical assistance of A. DOULIN and \\ J. BARAUD
}

From the Equipe de Recherche Associée au CNRS No. 334, Centre Hospitalo-universitaire de Nantes, France

SUMMARY The effects of drugs which change the bile-salt-independent fraction of bile flow on $\mathrm{Na}^{+} \mathrm{K}^{\mathrm{a}+}$ and $\mathrm{Mg}^{2+}$ activated ATPases were studied in membrane fractions rich in bile canaliculi.

The administration of phenobarbital caused no induction of these enzymes which could explain the increased bile flow observed in the rat.

Rose bengal, in addition to its strong photoxidative inhibition of both ATPases, inhibits the $\mathrm{Na}^{+} \mathrm{K}^{+}$ATPase of rat and rabbit bile canaliculi in the absence of light. A closely related substance, uranine, inhibits neither bile flow nor $\mathrm{Na}^{+} \mathrm{K}+\mathrm{ATPase}$. Inhibition of this enzyme by rose bengal may therefore be responsible for the observed effects of this dye on bile flow independent of bile salts.

Phenobarbital increases the bile flow of the rat (Hart, Guarino, and Adamson, 1969; Klaasen, 1969; Roberts and Plaa, 1967; Robinson, 1969a and b; Berthelot, Erlinger, Dhumeaux, and Preaux, 1970); rose bengal lowers this flow in the rabbit (Dhumeaux, Erlinger, Benhamou, and Fauvert, 1970). Both actions seem to be due to alterations in the recently described bile salt-independent fraction of bile secretion (Berthelot et al, 1970; Dhumeaux et $a l, 1970)$. We attempted to investigate whether these effects were operated through changes in ATPase activities in plasma membranes of the hepatocytes.

\section{Material and Methods}

HEPATIC PLASMA MEMBRANES OF RATS

TREATED WITH PHENOBARBITAL

Administration of phenobarbital

Male Charles River rats weighing 180-200 g were separated into two groups. One received daily injections of sodium phenobarbital, dissolved in isotonic saline $(16 \mathrm{mg} / \mathrm{ml} ; 8 \mathrm{mg} / 100 \mathrm{~g}$ of body weight) for 10 days. The control group had a daily injection of isotonic saline.

\section{Preparation of plasma membranes}

At least 18 hours after the last injection the rats

${ }^{2}$ This investigation was supported by INSERM grant no. 7130794.

Received for publication 21 August 1972. were stunned (two rats for each preparation); their livers were perfused with cold $1 \mathrm{mM} \mathrm{NaHCO}$ then homogenized in a glass-teflon potter using $10 \mathrm{ml}$ of the same solution for each gram of liver and diluted three times. Membranes were prepared according to the technique of Pfleger, Anderson, and Snyder (1968) slightly modified and adapted to a Spinco BIV zonal rotor.

The membrane fraction appeared on the $280 \mathrm{~m} \mu$ absorption curve of the final effluent as a slightly assymetrical peak (density from $1 \cdot 17$ to $1 \cdot 20$ ) (Fig. 1). This fraction was diluted with half a volume of $1 \mathrm{mM} \mathrm{NaHCO}$, and centrifuged in a SW 25.1 rotor at $66000 \mathrm{~g}$ for 10 minutes. The pellet was homogenized again in $30 \mathrm{ml}$ of bicarbonate solution and centrifuged for 10 minutes at $600 \mathrm{~g}$ to discard mitochondria and smaller membrane fragments. The resulting pellet, homogenized once again in $5 \mathrm{ml}$ distilled water, was used for enzyme assays. The whole process took six hours. Some of the preparations were examined under the electron microscope.

\section{Chemical determinations}

The following assays were performed as soon as the final membrane suspension was obtained: protein (Lowry, Rosebrough, Farr, and Randall, 1951), succinodehydrogenase (SDH) (Pennington, 1961), glucose-6-phosphatase (G-6-Pase) (Swanson, 1955), 5-nucleotidase (5'AMPase) (Heppel and Hilmoe, 1955). The ATPases were assayed using a slight 


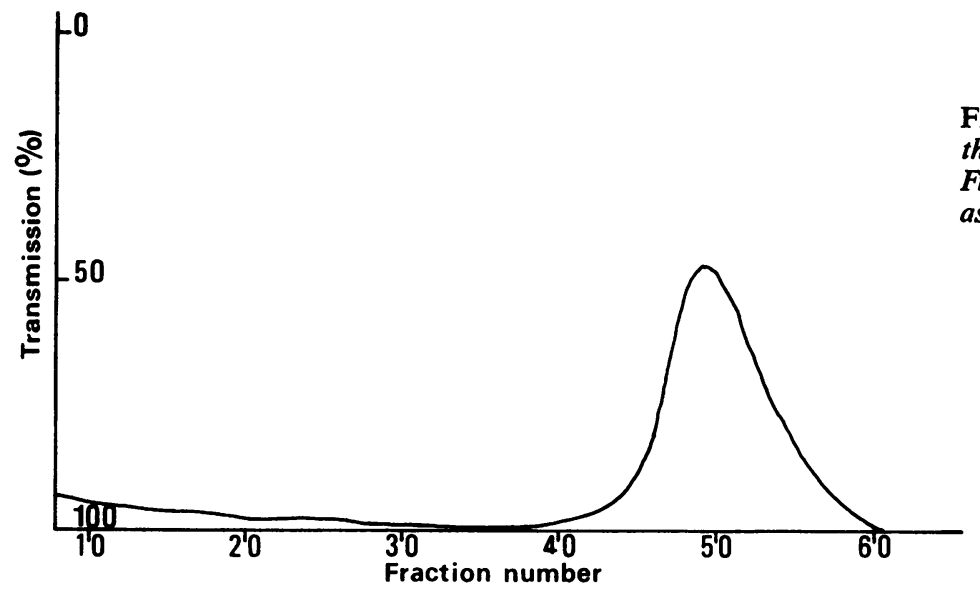

Fig. $1280 m \mu$ transmission curve of the final effluent of the zonal rotor. Fractions 45 to 55 were used for enzyme assay and microscopic observations.

modification of the method described by Wheeler and Whittam (1962). $\mathrm{Na}^{+} \mathrm{K}^{+}$ATPase activity was defined as the difference between the activities measured without ouabain in the incubation medium

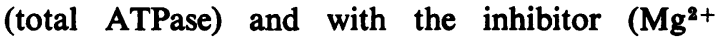
activated ATPase). The same results had been obtained in pilot experiments when Tris-ATP, prepared according to Järnefelt (1961), was used with and without $\mathrm{Na}^{+}$according to Emmelot and Bos (1966). Enzyme activities were also assayed in whole liver homogenates. All activities were expressed as moles of substrate transformed $/ \mathrm{hr} / \mathrm{mg}$ protein. Means were calculated \pm SD and results were compared using Student's t test.

EFFECTS OF ROSE BENGAL AND URANINE ON ATPASE ACTIVITIES OF LIVER PLASMA

MEMBRANES IN THE RAT AND THE RABBIT Membranes were prepared as indicated above from normal male Charles River rats. The effects of different concentrations of rose bengal and uranine (from 0.13 to $17 \mathrm{nmole} / \mathrm{ml}$ incubation medium) upon 5 nucleotidase, $\mathbf{M g}^{2+}$ activated ATPase, and $\mathrm{Na}^{+} \mathrm{K}+$ ATPase activities were studied. Sodium activation was used instead of ouabain inhibition to distinguish between the different ATPase activities, since interference between rose bengal and ouabain was observed. When rose bengal was used assays were performed in daylight and in the dark. In the latter situation minimal exposure to red light was used for adding rose bengal, substrate, and, 10 minutes later, trichloracetic acid to the incubation medium. The effect of uranine was assayed only in the dark, using yellow light during pipetting.

The same preparation procedures and enzymatic assays were carried out for rabbit liver.

All results were expressed as indicated above.
Results

MEMBRANE FRACTIONS

The electron microscope showed that membrane fractions were mainly composed of bile canaliculi (Figs. 2 and 3). Concentrations of marker enzymes in the rat membrane fractions were comparable to those observed by other authors (Emmelot and Bos, 1966; Coleman, Michell, Finean, and Hawthorne, 1967; Weaver and Boyle, 1969; Hinton, Dobrota, Fitzsimons, and Reid, 1970) as far as $\mathbf{M g}^{2+}$ activated ATPase (94 \pm 37.5), $\mathrm{Na}^{+} \mathrm{K}^{+}$ATPase (17.3 $\left.\pm 7 \cdot 5\right)$, and 5 nucleotidase $(46.6 \pm 17 \cdot 6)$ were concerned. Mitochondrial (SDH = 1.08 \pm 0.97) and microsomal contaminants (G-6-Pase $=\mathbf{5 . 8} \pm \mathbf{3 \cdot 3}$ ) were somewhat higher.

A study of marker enzymes of plasma membranes has not previously been published for the rabbit. ATPase activity was similar to that of rat plasma membranes $\left(\mathrm{Mg}^{2+}\right.$ activated ATPase: $66 \pm 38$; $\mathrm{Na}^{+} \mathrm{K}+$ ATPase $\left.11 \pm 6\right)$; 5-nucleotidase was very low (6.7 $\pm 2 \cdot 6)$ but no AMPase could bedemonstrated in rabbit plasma membranes by histochemical methods (Wachstein, 1963). Mitochondrial and microsomal contaminants were low (SDH: 0.38 \pm 0.22; G-6-Pase: 1.33 \pm 0.99).

\section{EFFECTS OF PHENOBARBITAL} ADMINISTRATION

For treated rats there was a $25 \%$ increase in the relative weight of the liver (Table I). The 5-nucleotidase activity of whole liver homogenates was $40 \%$ lower in treated animals when expressed as specific activity and $22.5 \%$ lower when referred to body weight (Table I). In plasma membranes specific activities of 5-nucleotidase, G-6-Pase, and SDH were not significantly altered (Table II). $\mathrm{Mg}^{2+}$ 


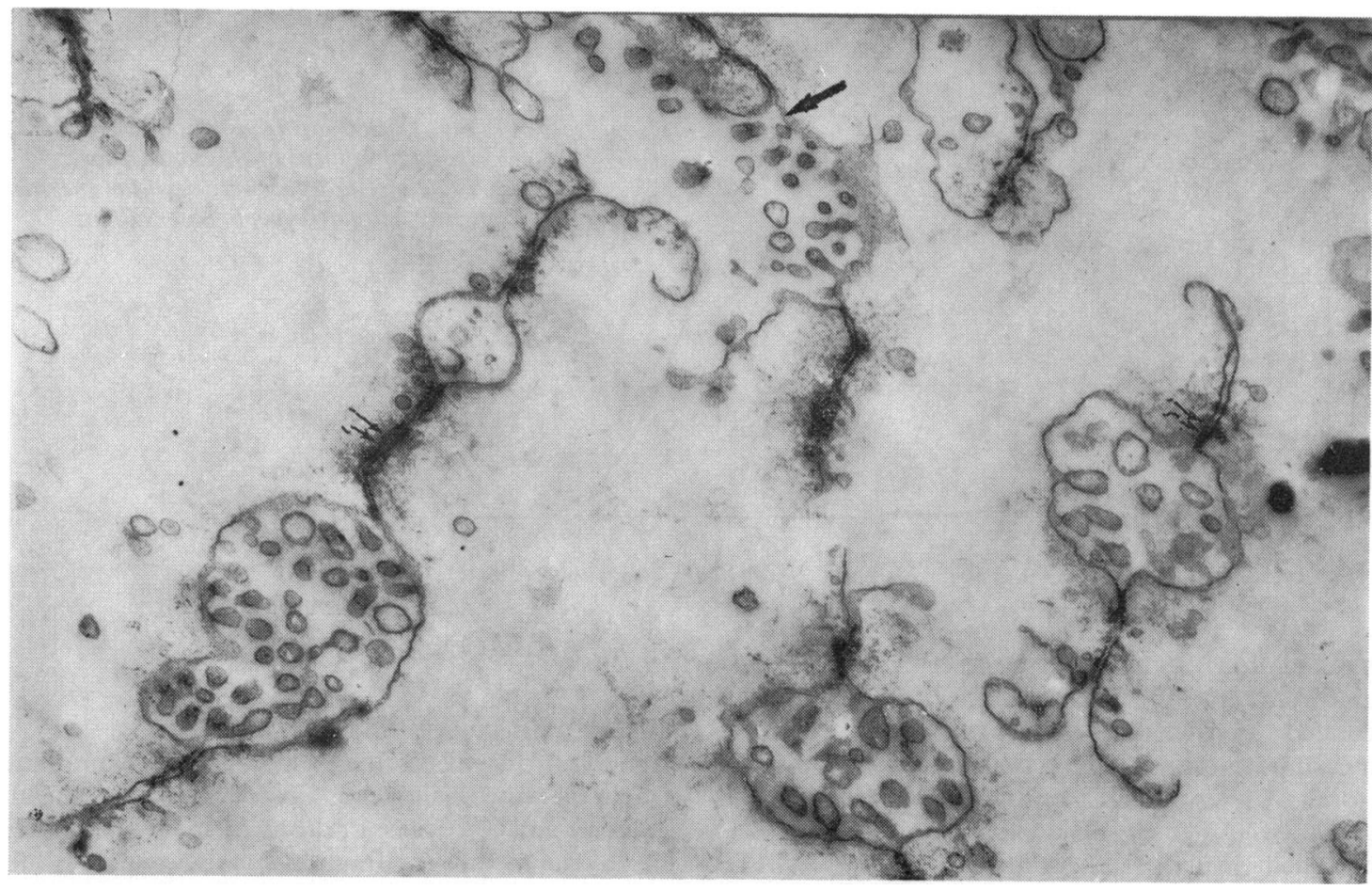

Fig. 2 Plasma membrane fraction from rat liver $(\times 18000)$ : it is mainly composed of the bile canaliculi closed by desmosomes $(\longrightarrow$ ) or occasionally ruptured $(\longrightarrow)$. Microvilli are numerous; some are swollen, others still seem to contain some cytosol.

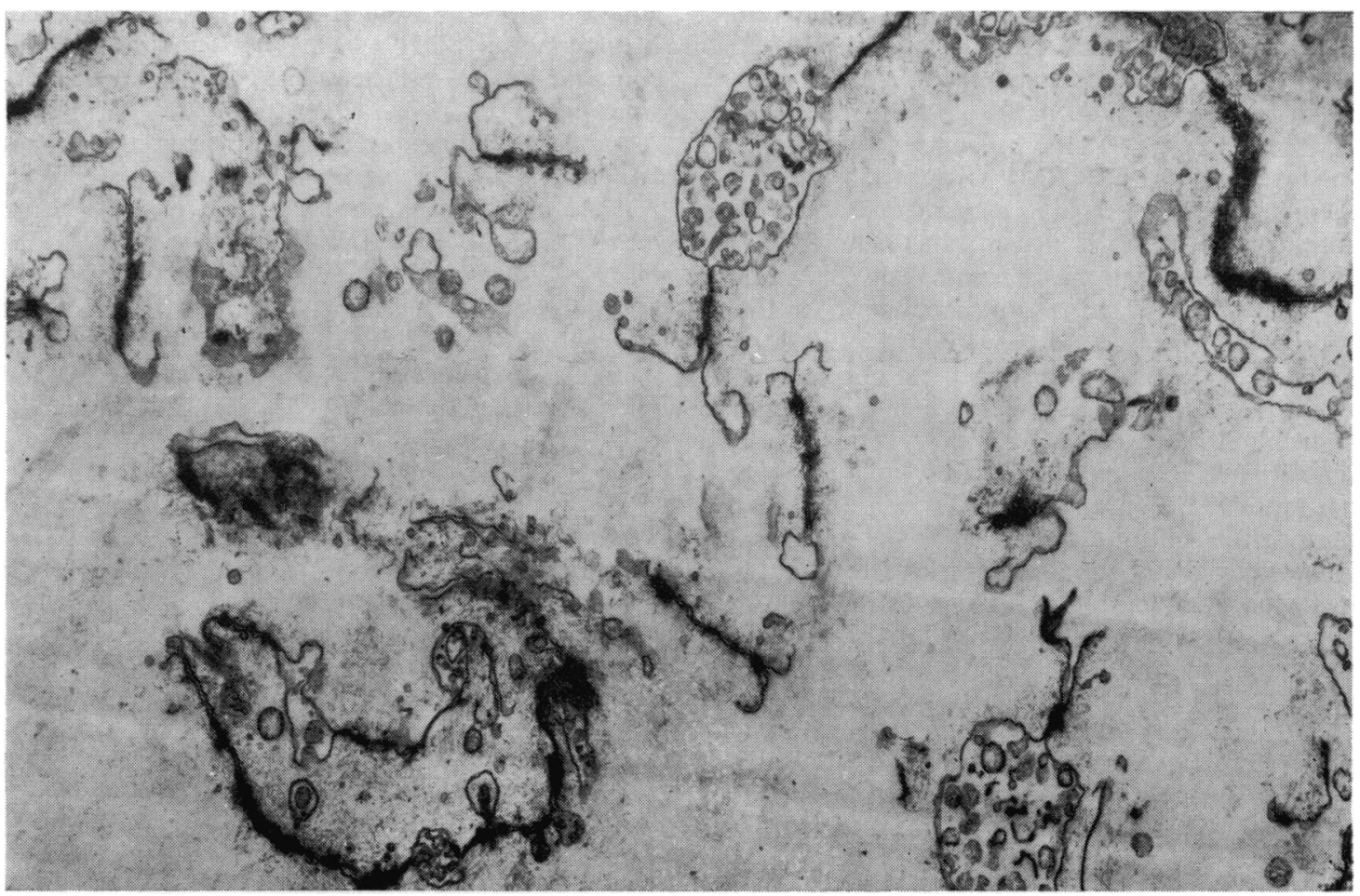

Fig. 3 Plasma membranes from rabbit liver $(\times 11000)$. The same structures are observed as in the rat. 


\begin{tabular}{|c|c|c|c|}
\hline \multirow[t]{2}{*}{ Rats } & \multirow{2}{*}{$\frac{\text { Liver Weight }}{\text { Body Weight }} \times 10^{-4}$} & \multirow[t]{2}{*}{$\begin{array}{l}\text { 5'AMPase } \\
\text { Specific Activity }\end{array}$} & $\begin{array}{l}\text { 5'AMPase } \\
\text { Activity }\end{array}$ \\
\hline & & & $\begin{array}{l}100 \mathrm{~g} \text { Body } \\
\text { Weight }\end{array}$ \\
\hline $\begin{array}{l}\text { Control } \\
\text { Treated } \\
\mathbf{P}\end{array}$ & $\begin{array}{l}469 \pm 71(15) \\
587 \pm 47(14) \\
<0.0005\end{array}$ & $\begin{array}{l}2.53 \pm 0.33(8) \\
1.49 \pm 0.33(8) \\
<0.0005\end{array}$ & $\begin{array}{l}2200 \pm 330(7) \\
1770 \pm 270(8) \\
<0.01\end{array}$ \\
\hline
\end{tabular}

Table I Liver weight and 5'AMPase activity in whole liver homogenate of rats treated with phenobarbital ${ }^{1}$

${ }^{2}$ Values given are the means \pm SD. Numbers in brackets are the numbers of experiments. This number is larger for liver weight than for enzyme activities since two livers were sometimes pooled for membrane preparation.

activated ATPase, and total ATPase activities were one third lower than in control animals; $\mathrm{Na}^{+} \mathrm{K}^{+}$ ATPase activities were not significantly different in the two groups but the results showed considerable scatter (Table II). The ratios of $\mathrm{Mg}^{2+}$ activated ATPase/5'-AMPase and $\mathrm{Na}^{+} \mathrm{K}^{+}$ATPase/5'-AMPase (Table III), and the ratio between the two ATPase activities were identical in both groups.

\begin{tabular}{|c|c|c|}
\hline \multirow[t]{2}{*}{ Rats } & $\mathrm{Mg}^{++}$ATPase & $\mathrm{Na}^{+} \mathrm{K}^{+} \mathrm{ATP}$ ase \\
\hline & $5^{\prime}$ AMPase & 5'AMPase \\
\hline $\begin{array}{l}\text { Control } \\
\text { ( } 9 \text { experiments) }\end{array}$ & $2.11 \pm 0.85$ & $0.43 \pm 0.26$ \\
\hline $\begin{array}{l}\text { Treated } \\
\text { (9 experiments) }\end{array}$ & $2.08 \pm 0.88$ & $0.42 \pm 0.34$ \\
\hline $\mathbf{P}$ & NS & NS \\
\hline
\end{tabular}

Table III Ratios of $\mathrm{Mg}^{2+}$ activated ATPase and $\mathrm{Na}^{+} \mathrm{K}^{+}$ATPase to $5^{\prime}$ AMPase activities in plasma membrane of rats treated with phenobarbital ${ }^{1}$

${ }^{1}$ Values given are the means \pm SD.

EFFECTS OF ROSE BENGAL AND URANINE ON PLASMA MEMBRANES IN RAT AND RABBIT LIVER

In the rat rose bengal had no effect on 5-nucleotidase. In daylight (Fig. 4) it inhibited $\mathbf{M g}^{2+}$ activated ATPase $(50 \%$ inhibition with 2.5 nmoles $/ \mathrm{ml})$; $\mathrm{Na}^{+} \mathrm{K}^{+}$ATPase was much more sensitive $(50 \%$ inhibition with $0 \cdot 3 \mathrm{nmoles} / \mathrm{ml}$ ). In the dark (Fig. 4)

\begin{tabular}{|c|c|c|c|c|c|c|c|}
\hline Rats & & 5'AMPase & Total ATPase & $\mathrm{Mg}^{++}$ATPase & $\mathrm{Na}^{+} \mathrm{K}^{+}$ATPase & $G 6 P$ & $S D H$ \\
\hline $\begin{array}{l}\text { Control } \\
\text { Treated } \\
\mathbf{P}\end{array}$ & $\begin{array}{l}\text { (9 experiments) } \\
\text { (9 experiments) }\end{array}$ & $\begin{array}{l}46.6 \pm 17.6 \\
33.5 \pm 15.3 \\
N S\end{array}$ & $\begin{array}{l}111.5 \pm 38.4 \\
72 \pm 16 \\
<0.0005\end{array}$ & $\begin{array}{l}94 \cdot 2 \pm 37 \cdot 5 \\
60.6 \pm 18 \cdot 2 \\
<0.0125\end{array}$ & $\begin{array}{l}17 \cdot 3 \pm 7 \cdot 5 \\
11 \cdot 3 \pm 7 \cdot 7 \\
N S\end{array}$ & $\begin{array}{l}5 \cdot 8 \pm 7 \cdot 5 \\
7 \cdot 1 \pm 5 \cdot 6 \\
\text { NS }\end{array}$ & $\begin{array}{l}1.08 \pm 0.97 \\
2.4 \pm 2 \\
N S\end{array}$ \\
\hline
\end{tabular}

Table II Enzyme activities in plasma membranes of rats treated with phenobarbital ${ }^{1}$

${ }^{2}$ Values given are the means \pm SD.

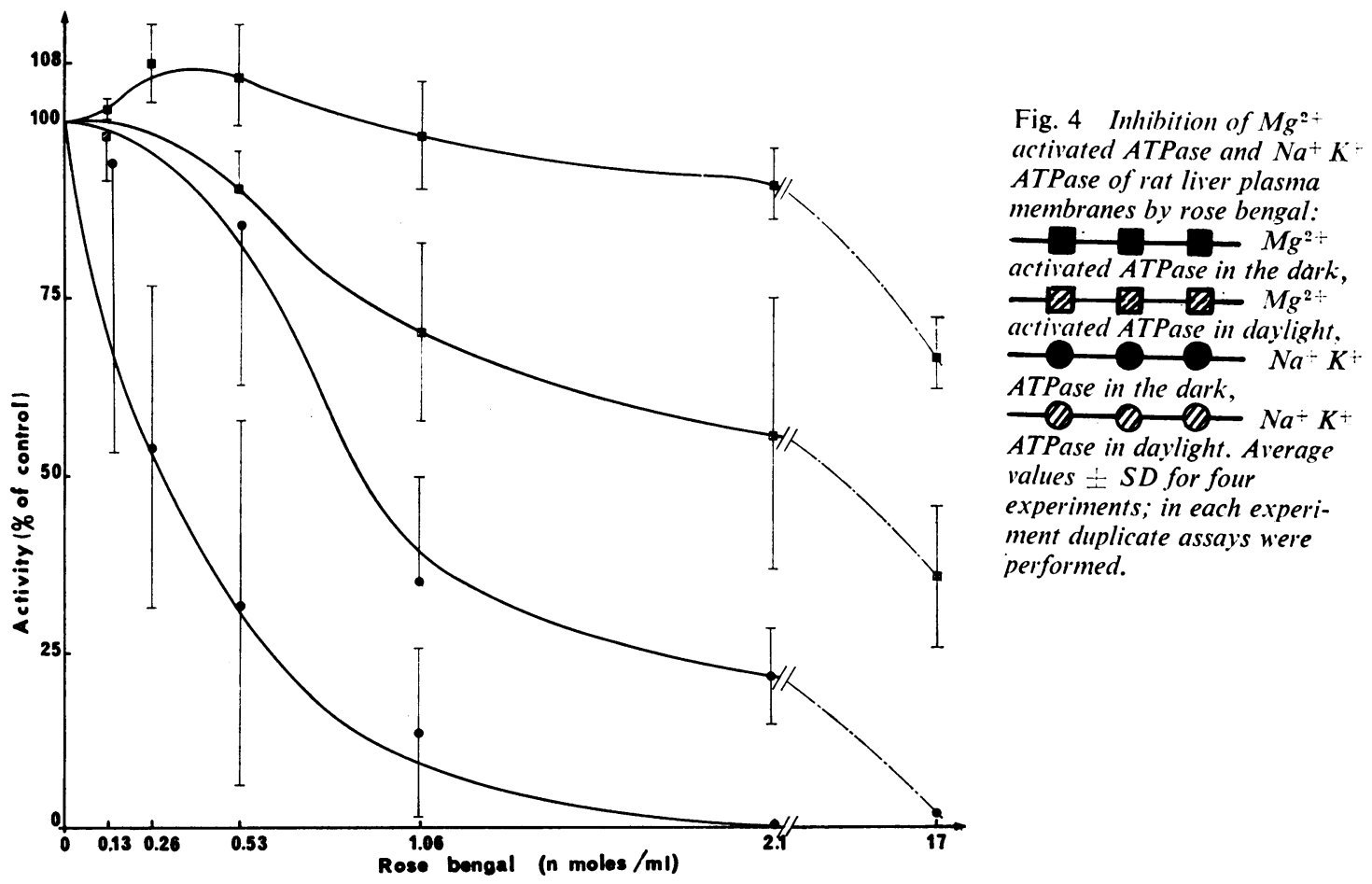




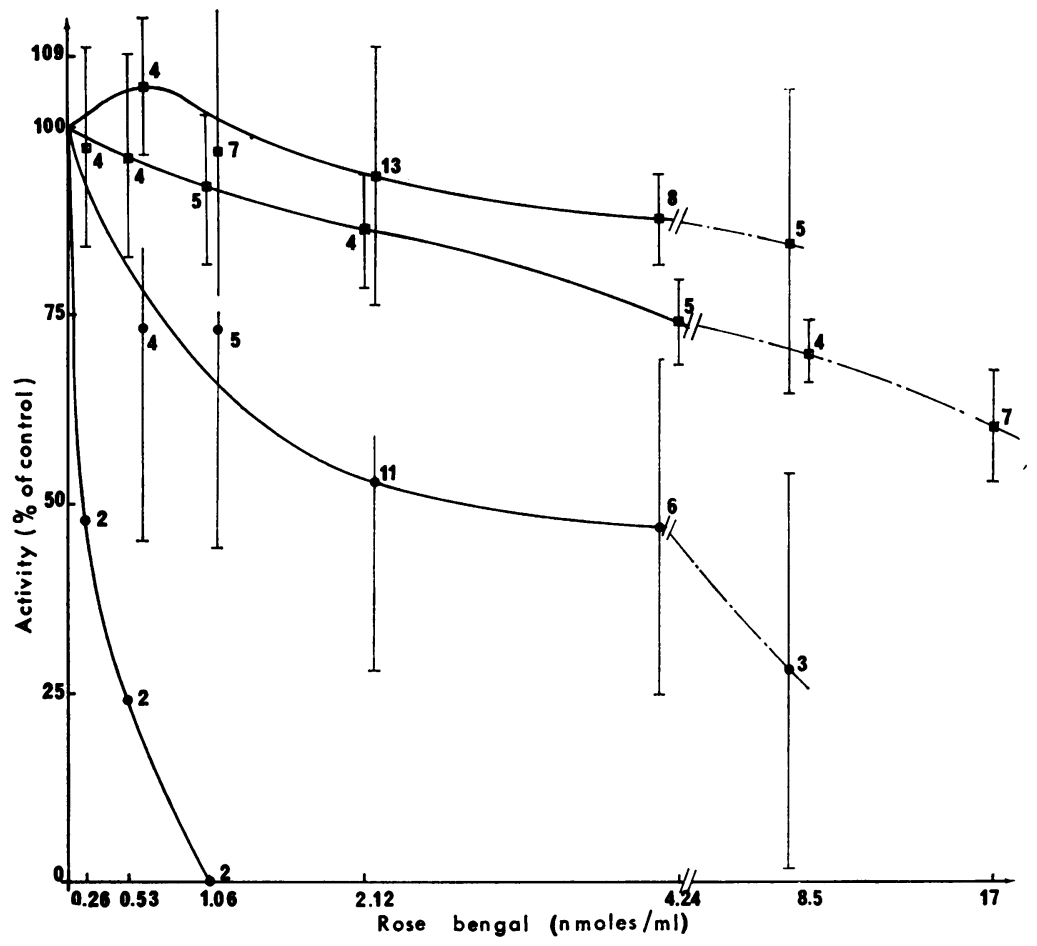

Fig. 5 Inhibition of $\mathbf{M g}^{2-}$ activated ATPase and $\mathrm{Na}^{+} \mathrm{K}^{+}$ ATPase of rabbit liver plasma membranes by rose bengal: ATPase in the dark $\mathrm{Mg}^{2}$ :Q $\mathbf{M g}^{2-}$ ATPase in daylight, $\mathrm{Na}^{-} \mathrm{K}^{+}$ ATPase in the dark, - $\mathrm{Na}^{+} \mathrm{K}^{+}$ ATPase in daylight. Average values $\doteq S D$. Number of experiments is indicated.

$\mathrm{Mg}^{2+}$ ATPase was slightly activated by low concentrations of the dye $(0.25$ to $0.5 \mathrm{nmoles} / \mathrm{ml})$ and slightly inhibited by larger ones (only $25 \%$ inhibition with $17 \mathrm{nmoles} / \mathrm{ml}) ; 50 \%$ inhibition of $\mathrm{Na}^{+} \mathrm{K}^{+}$ ATPase was observed with $0.85 \mathrm{nmoles} / \mathrm{ml}$. Uranine had no action on any of the assayed enzymes.

In the rabbit the effect of rose bengal on both ATPase activities in the dark was slightly less important than that observed in the rat (Fig. 5). Uranine had no effect.

\section{Discussion}

A correlation between $\mathrm{Na}^{+} \mathrm{K}^{+}$ATPase and the bile-salt-independent fraction of bile secretion has been suggested since this fraction is inhibited by ouabain and ethacrynic acid in the rabbit (Erlinger, Dhumeaux, and Benhamou, 1969; Erlinger, Dhumeaux, Berthelot, and Dumont, 1970). In this species rose bengal has also been shown to inhibit the bile-salt-independent fraction in the secretion of bile by an unknown mechanism (Dhumeaux et al, 1970). Rose bengal inhibition of the $\mathrm{Na}^{+} \mathrm{K}^{+}$ATPase of red cells in daylight has been shown to be responsible for the haemolytic action of this dye (Duncan and Bowler, 1969). In daylight rose bengal inhibits both ATPases in membrane fractions composed mainly of bile canaliculi. However such photo-dependent inhibition cannot occur in the abdominal cavity. The inhibition of red cell $\mathrm{Na}^{+} \mathrm{K}^{+}$ ATPase in the dark is a controversial matter (Blaiklock and Green, 1971; Borgese and Green, 1962). Liver plasma membrane $\mathrm{Na}^{+} \mathrm{K}^{+}$ATPase activity is inhibited in the dark by concentrations 1000 times lower than those produced in rabbit bile by an intravenous injection of rose bengal which lowers the bile flow, that is $6 \mathrm{mg} / \mathrm{ml}$ (Dhumeaux, personal communication). Uranine, which does not lower bile flow (Dhumeaux et al, 1970), in spite of its chemical resemblance to rose bengal (disodium fluorescein versus disodium tetrachlorotetraiodofluorescein), has no effect on either ATPase activitiy in vitro. The inhibitory action of rose bengal on the bile-salt-independent fraction in the bile secretion of the rabbit may therefore have the same mechanism as that of ouabain and ethacrynic acid, which would be consistent with the concept attributing the secretion of this fraction in rabbit liver to the activity of $\mathrm{Na}^{+} \mathrm{K}^{+}$ATPase.

In the rat the problem is more confused. According to a brief preliminary report (Berthelot, 1971), ouabain and ethacrynic acid do not inhibit in vivo the bile-salt-independent fraction of bile secretion in the rat; the low sensitivity of the rat to cardiac glycosides was considered to be a possible reason for this. Recently inhibition of the bile-salt-independent 
fraction in bile flow by extremely high concentrations of scillaren has been described in the isolated perfused rat liver (Boyer, 1971). If the mechanism of this secretion is similar to that of the rabbit, rose bengal should also inhibit secretion of this fraction in the rat since in vitro the dye has much the same effect in both species. This inhibition is being studied.

Induction of $\mathrm{Na}^{+} \mathrm{K}^{+}$ATPase by phenobarbital in rat bile canaliculi would have been expected to yield some further evidence on the role of this enzyme in bile flow. The present results show no such induction. In the membrane fraction, the ratio of both ATPases activities to the 5-nucleotidase activity is unaffected by phenobarbital. The latter enzyme activity is significantly decreased when referred to liver weight. This decrease is still present although to a lesser extent when 5-nucleotidase activity is referred to body weight and cannot therefore result from a mere dilution of plasma membranes by the increase of microsomal protein, which itself lowers the specific activity of 5-nucleotidase in the whole homogenate. The mechanism for the increase in bile production by phenobarbital therefore remains unknown. It should be noted, however, that this increase has the same order of magnitude as the increase in liver weight (Berthelot et al, 1970) although other work has shown that all microsome inducers do not share this property in spite of the enlargement that they provoke in the liver (Klaasen, 1969).

Y. Laperche is Stagiaire de Recherche and Mme A. Launay Attachee de Recherche in the Institut National de la Santé et de la Recherche Médicale (INSERM).

We wish to thank Mrs M. C. Oudea for the electron microscopic examination of the membrane preparations, P. Berthelot and S. Erlinger for fruitful discussion, and Miss M. H. d'Assumcao for her help in preparing the manuscript.

\section{References}

Berthelot, P. (1971). Answer to a comment. Gastroenterology, 60, 614615.

Berthelot, P., Erlinger, S., Dhumeaux, D., and Preaux, A. M. (1970). Mechanism of phenobarbital induced hypercholeresis in the rat. Amer. J. Physiol., 219, 809-813.

Blaiklock, R. G., and Green, J. W. (1971). Nonphoto-oxidative eosin $\mathrm{Y}$ inhibition of $\mathrm{Na}+\mathrm{K}+\mathrm{ATPase}$ activity in the human erythrocyte membrane. Arch. Biochem., 145, 43-49.
Borgese, T. A., and Green, J. W. (1962). Cation exchanges and glycolytic inhibition by photosensitized rabbit erythrocytes. J. cell. comp. Physiol., 59, 215-222.

Boyer, J. L. (1971). Canalicular bile formation in the isolated perfused rat liver. Amer. J. Physiol., 221, 1156-1163.

Coleman, R., Michell, R. H., Finean, J. B., and Hawthorne, J. N. (1967). A purified plasma membrane fraction isolated from rat liver under isotonic conditions. Biochim. biophys. Acta (Amst.), 135, 573-579.

Dhumeaux, D., Erlinger, S., Benhamou, J. P., and Fauvert, R. (1970). Effects of rose bengal on bile secretion in the rabbit: inhibition of bile salt-independent fraction. Gut, 11, 134-140.

Duncan, C. J., and Bowler, K. (1969). Permeability and photoxidative damage of membrane enzymes. J. cell. comp. Physiol., 74, 259272.

Emmelot, P., and Bos, C. J. (1966). Studies on plasma membranes, III. $\mathrm{Mg}^{++}$-ATPase, $\left(\mathrm{Na}^{+}, \mathrm{K}^{+}, \mathrm{Mg}^{++}\right)$-ATPase and 5'nucleotidase activity of plasma membranes isolated from rat liver. Biochim. biophys. Acta (Amst.), 120, 369-382.

Erlinger, S., Dhumeaux, D., and Benhamou, J. P. (1969). Effect on bile formation of inhibitors of sodium transport. Nature (Lond.), 223, 1276-1277.

Erlinger, S., Dhumeaux, D., Berthelot, P., and Dumont, M. (1970). Effect of inhibitors of sodium transport on bile formation in the rabbit. Amer. J. Physiol., 219, 416-422.

Hart, L. G., Guarino, A. M., and Adamson, R. H. (1969). Effects of phenobarbital on biliary excretion of organic acids in male and female rats. Amer. J. Physiol., 217, 46-52.

Heppel, L. A., and Hilmoe, R. J. (1955). '5' Nucleotidases. In Methods in Enzymology, edited by S. P. Colowick and N. O. Kaplan, vol. II, pp. 546-550. Academic Press, New York and London.

Hinton, R. H., Dobrota, M., Fitzsimons, J. T. R., and Reid, E. (1970). Preparation of a plasma membrane fraction from rat liver by zonal centrifugation. Europ. J. Biochem., 12, 349-361.

Järnefelt, J. (1961). Sodium stimulated adenosinetriphosphatase in microsomes from rat brain. Biochim. biophys. Acta (Amst.), 48, 104-110.

Klaassen, C. D. (1969). Biliary flow after microsomal enzyme induction. J. Pharmacol. exp. Ther., 168, 218-223.

Lowry, O. H., Rosebrough, N. J., Farr, A. L., and Randall, R. J. (1951). Protein measurement with the folin phenol reagent. J. biol. Chem., 193, 265-275.

Pennington, R. J. (1961). Mitochondrial succinate-tetrazolium reductase and adenosine triphosphatase. Biochem. J., 80, 649654.

Pfleger, R. C., Anderson, N. G., and Snyder, F. (1968). Lipid class and fatty acid composition of rat liver plasma membranes isolated by zonal centrifugation. Biochemistry, 7, 2826-2833.

Roberts, R. J., and Plaa, G. L. (1967). Effect of phenobarbital on the excretion of an exogenous bilirubin load. Biochem. Pharmacol., 16, 827-835.

Robinson, S. H. (1969a). Phenobarbital-induced rise in bilirubin conjugation in vivo. (Abstr.). Clin. Res., 17, 309.

Robinson, S. H. (1969b). Increased bilirubin conjugation in heterozygous Gunn rats treated with phenobarbital. Nature (Lond.), 222, 990-991.

Swanson, M. A. (1955). Glucose 6 phosphatase. In Methods in Enzymology, edited by S. P. Colowick and N. O. Kaplan, vol. II, pp. 541-543. Academic Press, New York and London.

Wachstein, M. (1963). Cyto and histochemistry of the liver. In The Liver, edited by Ch. Rouiller, vol. I, pp. 137-194. Academic Press, New York and London.

Weawer, R. A., and Boyle, W. (1969). Purification of plasma membranes of rat liver: application of zonal centrifugation to isolation of cell membranes. Biochim. biophys. Acta (Amst.), 173, 377-388.

Wheeler, K. P., and Whittam, R. (1962). Some properties of a kidney adenosine triphosphatase relevant to active cation transport. Biochem. J., 85, 495-507. 